\title{
ENDOSCOPIC TREATMENT OF VESICAL AND URETHRAL PERFORATIONS AFTER TENSION-FREE VAGINAL TAPE (TVT®) PROCEDURE FOR FEMALE STRESS URINARY INCONTINENCE
}

Fabio Baracat, Anuar Ibrahim Mitre, Hideki Kanashiro, Nelson Ileo Dias Montellato

Baracat F, Mitre AI, Kanashiro H, Montellato NID. Endoscopic treatment of vesical and urethral perforations after tensionfree vaginal tape $\left(\right.$ TVT $\left.^{\circledR}\right)$ procedure for female stress urinary incontinence. Clinics. 2005;60(5):397-400.

Stress urinary incontinence is a problem that is prevalent in women, and its treatment with minimally invasive techniques using synthetic materials has increased recently, although the procedure has also brought increased occurrence of specific complications such as vesical and urethral perforations. We describe 11 cases of endoscopic correction of vesical and urethral perforations due to the use of synthetic material for the treatment of stress urinary incontinence.

MATERIALS AND METHOD: Eleven patients were treated for complications after undergoing the TVT ${ }^{\circledR}$ (tension-free vaginal tape) procedure; 6 of them had the polypropylene tape inside the bladder, and 5 had erosion of the urethra. Endoscopic resection of the polypropylene tapes was performed on all patients.

RESULTS: A 6-month follow-up with cystoscopic control showed that the procedures were successful with complete relief of the symptoms except for 1 patient who persisted with the polypropylene tape in the bladder. This patient underwent a new endoscopic resection, and the cystoscopic control exam was normal 3 months later.

CONCLUSION: Endoscopic resection of intravesical and intraurethral synthetic tapes can be considered a good alternative for the treatment of complications resulting from the TVT procedure.

KEYWORDS: Stress urinary incontinence. Erosion. Suburethral sling.

Stress urinary incontinence (SUI) affects $10 \%$ to $20 \%$ of women in the general population, ${ }^{1}$ generating annual treatment costs of about 10 billion dollars in the USA alone. ${ }^{2}$ There are several problems arising from SUI that affect the emotional and productive life of the women with this condition, including urine odor, cutaneous irritation, and urinary tract infection as well as hygienic and psychosocial limitations. ${ }^{3}$ Its treatment involves surgical procedures. Several techniques have been described, which shows that its physiopathology is not completely understood. During recent decades, retropubic suspension through the

Division of Clinical Urology, Hospital das Clínicas, Faculty of Medicine, University of São Paulo - São Paulo/SP, Brazil.

Email: hideki.kanashiro@sbu.org.br

Received for publication on May 14, 2005.

Accepted for publication on July 19, 2005. colposuspension of Burch $^{4}$ has been considered the gold standard for the correction of urinary incontinence. ${ }^{5}$

According to the theory proposed by DeLancey in $1994,{ }^{6}$ increases of the abdominal pressure lead to compression of the urethra against its natural anatomical supports ("hammock" theory). At present, this is the main focus of the new techniques for the surgical correction of SUI, and it was McGuire ${ }^{7}$ who reintroduced the technique of suburethral support with the aponeurosis of the rectus abdominal muscles and combined abdominal-vaginal surgical access.

Ulmsten et al, based on investigative experiments to reduce the operative time and postoperative recovery, developed the tension-free vaginal tapes $\left(\mathrm{TVT}^{\circledR}\right)$ as an ambulatory and minimally invasive technique for the treatment of this pathology. ${ }^{8}$ 
The use of TVT in the correction of stress urinary incontinence has been widespread in our country, as well as in other countries, with promising results that attain cure rates greater than $85 \% .^{9-12}$

However, the use of minimally invasive surgical methods using synthetic material for the surgical treatment of SUI can cause specific complications that are uncommon with traditionally used techniques.

Voiding dysfunction is the most frequent complication after the surgical correction of SUI, occurring in $1 \%$ to $15 \%$ of the cases..$^{13}$

With the use of TVT, 2 types of complications have been described: a precocious one, usually bladder perforation that is probably caused by technical failure during the procedure; and a late one, due to urethral erosion caused by the synthetic material (polypropylene) of the tape. ${ }^{18}$

It should be pointed out that the main appeal of the modern procedures for the treatment of SUI is that it is minimally invasive, yet their peculiar complications should be considered.

\section{MATERIALS AND METHODS}

Between July of 2002 and January of 2004, 6 outpatients from other institutions were referred to us for treatment of intravesical polypropylene tape, 1 of them presenting 3 fragments of the tape.

In the same period, 5 other patients were treated for polypropylene tape in the urethral lumen, and of these, 3 were outpatients and 2 were from our institution. The complaints of patients with intravesical tape were an incomplete voiding sensation with episodes of recurring urinary tract infections occurring between the first and the third postoperative months. The ultrasound of the urinary tract identified in all those patients the presence of a fixed strange body inside the bladder (Figure 1).

In the cases of the tape in the urethral lumen, the predominant clinical symptomatology was difficulty in emptying the bladder, beginning between the 7th and the 9th postoperative months, with complaints of progressive voiding dysfunction and alteration of the urinary flow. They also presented urinary tract infection.

Abdominal ultrasound was ineffective in diagnosing intraurethral tapes in all of these cases, as confirmed by urethrocystoscopy (Figure 2). Both groups of patients underwent endoscopic incision and the removal of the intraluminal segment of the polypropylene tape.

A rigid nephroscope (26 Fr) was introduced into the urethra, laparoscopic scissors of $5 \mathrm{~mm}$ were introduced in the working duct of the nephroscope, and the tapes withdrawn from the interior of the bladder or of the urethra.

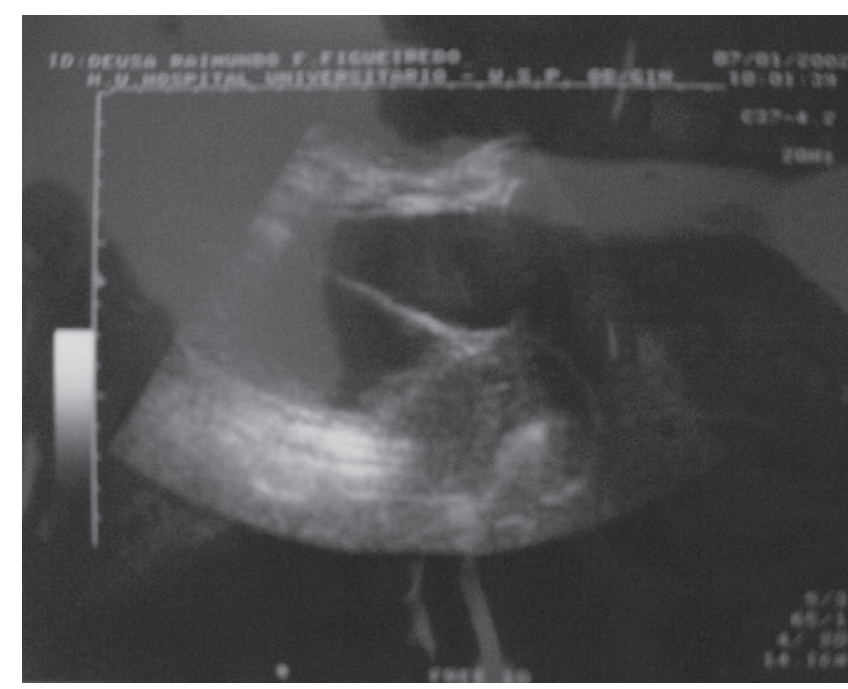

Figure 1 - Achado ultrassonográfico de faixa de propilene na luz vesical

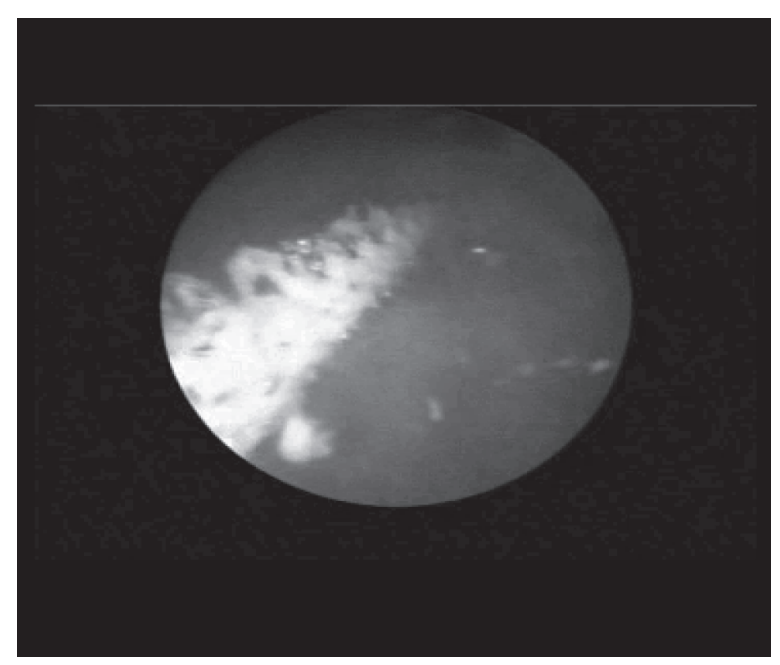

Figure 2 - Visão endoscópica com faixa de propilene intra vesical

In the cases of intravesical tapes, a $5 \mathrm{~mm}$ trocar was introduced suprapubically, followed by laparoscopic Maryland tweezers for fixation and traction of the tape inside the bladder, thus facilitating its incision in the bladder access. All the patients were discharged the day following surgery, and none presented infectious complications.

The patients of both groups underwent endoscopic control exams 3 and 6 months after surgery.

\section{RESULTS}

In all patients, the clinical conditions were reversed and resolved except for the patient with 2 intravesical polypropylene tapes, who presented lithiasis in the bladder dome at the 6-month cystoscopic control exam and underwent an additional endoscopic excision of the remain- 
ing tape. A new cystoscopy 3 months later was normal.

The other patients had complete relief of the previous symptoms. Concerning SUI, all the patients that had intravesical polypropylene tape were continent; Of the patients with intraurethral tape, 3 had reoccurrence of SUI, and they underwent the "autologous sling" technique of the, with successful results.

\section{DISCUSSION}

The new minimally invasive techniques for the surgical treatment of SUI are accompanied by new complications $^{14}$.

Synthetic materials have been widely used, and they present a rate of late complications, such as vaginal and urethral erosions, of about $1.8 \%$, which is greater than when autologous materials are used. ${ }^{15}$ Additionally, late detected intraoperative lesions can raise diagnosis and management problems. These lesions can be caused by lack of cystoscopic time or the surgeons' inappropriate training. They may also be due to the technical difficulty of visualization of these synthetic materials during the cystoscopy, or even be the consequence of inadequate use of the equipment for the procedure (for instance, use of hysteroscope instead for cystoscope).

Other described lesions for instance, lesions of the intraperitoneal viscera ${ }^{16}$ and vessels, resulting from the misdirection of the instruments and due to the lack of vision of the needle's course, lesions leading to the patient's death ${ }^{17}$ have all re-established the discussion of minimally invasive procedures substitutes to traditional techniques. Some advantages of minimally invasive procedures are obvious, such as reduced operative time and shorter and more comfortable postoperative recovery; however, complications related to the material used and to the surgeon's inadequate skills are increasing, the latter often aggravated when a procedure that is considered relatively easy is mistakenly underestimated by the surgeon.
Although not published, in our experience with 259 cases of TVT, different complications have been noted, such as problems caused by the suburethral use of synthetic materials (5 cases of urethral erosion), as well as problems caused by incorrect intrasurgical diagnosis, with the presence of the intravesical polypropylene tape ( 6 cases). ${ }^{18}$ The vesical transfixion is due to the absence of the cystoscopic time or due to the lack of familiarity with the cystoscope or the incorrect use of right-angle optics, as for instance, with the hysteroscope.

Urologic endoscopy of the bladder should be accomplished with extreme care during the minimally invasive procedures, regarding the technique as it should be, since the visualization of the polypropylene tape inside the bladder can be difficult. The use of a 70-degree optics for the urethrocystoscopy to locate the sites of vesical perforation is advisable, generally at the ten o'clock and the two o'clock positions on bladder neck; full vesical distention is needed for the endoscopic procedure, as the tapes may be hidden by folds of the mucous of the bladder if it is not well distended. These are relevant precautions that help to diminish the rates of complications with the minimally invasive procedures.

The TVT procedure represents a signal progress in the treatment of SUI, but being minimally invasive, these procedures should only be performed after complete surgical training and without omitting any of the steps. In terms of continence, the results obtained with the use of this method are similar to those of the slings of autologous aponeurosis and have tolerable rates of complications. ${ }^{19}$ Therefore, if performed appropriately, they are attractive alternatives in the treatment of SUI.

\section{CONCLUSIONS}

The endoscopic method can be considered a good alternative for the treatment of late diagnosed vesical transfixion due to synthetic tapes, as well as for the treatment of the urethral erosion.

\section{RESUMO}

Baracat F, Mitre AI, Kanashiro H, Montellato NID. Tratamento endoscópico das perfurações vesicais e uretrais devidas à utilização do suporte suburetral sintético para correção de incontinência urinária de esforço. Clinics. 2005;60(5):397-400.

A incontinência urinária de esforço é um problema prevalente em mulheres. As opções para seu tratamento vêm aumentando nos últimos tempos, havendo um direcionamento para as técnicas minimamente invasivas, com auxílio de material sintético. Com a utilização desses procedimentos, surgiram complicações incomuns, como perfuração vesical e uretral. As complicações estudadas foram devido à utilização de material sintético no tratamento de incontinência urinária de esforço e o tratamento endoscópico empregado. 
MATERIAL E MÉTODO: Onze pacientes foram tratadas com complicações decorrentes do tension-free vaginal tape, seis com faixa de polipropileno dentro da bexiga e cinco com erosão para uretra. Foi realizada ressecção endoscópica em todas as pacientes.

RESULTADOS: Uma paciente persistiu com a faixa de polipropileno e foi submetida à nova ressecção endoscópica e cistoscopia controle após três meses era normal.

CONCLUSÃO: Realização de ressecção endoscópica de faixas sintéticas intravesicais e intra-uretrais deve ser considerada uma boa alternativa no tratamento dessas complicações.

\section{UNITERMOS: Incontinência urinária de esforço. Ero- são. Sling suburetral.}

\section{REFERENCES}

1. Hunskaar S, Arnold EP, Burgio K, Diokno AC, Herzog AR, Mallett VT. Epidemiology and natural history of urinary incontinence. Int Urogynecol J Pelvic Floor Dysfunct. 2000;11(5):301-19.

2. Knowledge, attitudes, and practices of physicians regarding urinary incontinence in persons aged $>$ or $=65$ years-Massachusetts and Oklahoma, 1993. MMWR Morb Mortal Wkly Rep. 1995; 44(40):747, 753-4.

3. Elving LB, Foldspang A, Lam GW, Mommsen S. Descriptive epidemiology of urinary incontinence in 3,100 women age $30-59$. Scand J Urol Nephrol Suppl. 1989;125:37-43.

4. Burch JC. Cooper's ligament urethrovesical suspension for stress incontinence. Nine years' experience-results, complications, techniques. Am J Obstet Gynecol. 2002;187(2):513.

5. Jarvis GJ, Bent A, Cortesse A, Mcguire E, Milani R, Quartey J, et al. Surgical treatment incontinence in adult women-surgery of female lower genito-urinary fistulae. In: Abrams P. editor. Incontinence. Monaco: Health Publication; 1999. p. 639-56.

6. DeLancey JO. Structural support of the urethra as it relates to stress urinary incontinence: the hammock hypothesis. Am J Obstet Gynecol. 1994;170(6):1713-20.

7. Mcguire EJ, Lytton B. Pubovaginal sling procedure for stress incontinence. J Urol. 1978;119(1):82-4

8. Ulmsten U, Henriksson L, Johnson P, Varhos G. An ambulatory surgical procedure under local anesthesia for treatment of female urinary incontinence. Int Urogynecol J Pelvic Floor Dysfunct. 1996;7(2):81-5.

9. Meschia M, Pifarotti P, Bernasconi F, Guercio E, Maffiolini M, Magatti F et al. Tension-free vaginal tape: analysis of outcomes and complications in 404 stress incontinent women. Int Urogynecol J Pelvic Floor Dysfunct. 2001;12 Suppl 2:S24-S27.

10. Moran PA, Ward KL, Johnson D, Smirni WE, Hilton P, Bibby J. Tensionfree vaginal tape for primary genuine stress incontinence: a two-centre follow-up study. BJU Int. 2000;86(1):39-42.
11. Haab F, Sananes S, Amarenco G, Ciofu C, Uzan S, Gattegno B, et al Results of the tension-free vaginal tape procedure for the treatment of type II stress urinary incontinence at a minimum followup of 1 year. J Urol. 2001;165(1):159-62.

12. Nilsson CG, Kuuva N. The tension-free vaginal tape procedure is successful in the majority of women with indications for surgical treatment of urinary stress incontinence. BJOG. 2001;108(4):414-9.

13. Mishra VC, Mishra N, Karim OM, Motiwala HG. Voiding dysfunction after tension-free vaginal tape: a conservative approach is often successful. Int Urogynecol J Pelvic Floor Dysfunct. 2005;16(3):210-4.

14. Abouassaly R, Steinberg JR, Lemieux M, Marois C, Gilchrist LI, Bourque JL, et al. Complications of tension-free vaginal tape surgery: a multi-institutional review. BJU Int. 2004;94(1):110-3.

15. Jarvis GJ. Surgery for genuine stress incontinence. Br J Obstet Gynaecol. 1994;101(5):371-74.

16. Amna MB, Randrianantenaina A, Michel F. Colic perforation as a complication of tension-free vaginal tape procedure. J Urol. 2003;170(6 Pt 1):2387.

17. Walters MD, Tulikangas PK, LaSala C, Muir TW. Vascular injury during tension-free vaginal tape procedure for stress urinary incontinence. Obstet Gynecol. 2001;98(5 Pt 2):957-9.

18. Pit MJ. Rare complications of tension-free vaginal tape procedure: late intraurethral displacement and early misplacement of tape. J Urol. 2002; 167(2 Pt 1):647.

19. Nilsson CG, Kuuva N, Falconer C, Rezapour M, Ulmsten U. Longterm results of the tension-free vaginal tape (TVT) procedure for surgical treatment of female stress urinary incontinence. Int Urogynecol J Pelvic Floor Dysfunct. 2001;12 Suppl 2:S5-S8. 